\title{
ON THE COMPUTATION OF HEAT TRANSFER COEFFICIENTS FROM ENERGY-BALANCE GRADIENTS ON A GLACIER
}

\author{
By Michael Kuhn \\ (Institut für Meteorologie und Geophysik, Schöpfstrasse 4 I, A-6o2o Innsbruck, Austria)
}

\begin{abstract}
The turbulent flux of sensible heat in the energy balance of a glacier surface is assumed to be proportional to the temperature difference between the glacier surface and the atmosphere at the same level but outside the thermal influence of the glacier. The factor of proportionality between them is first explained in terms of friction velocity, roughness height, and stability function of the logarithmic wind and temperature profile. It is then derived from climatological records and measurements of the energy balance and its altitudinal gradients at Hintereisferner. Examples of the energy-balance components and their change with altitude are given for the entire ablation season as well as for short periods. The heat transfer coefficients derived have a mean value of $1.7 \pm 0.2 \mathrm{MJ} \mathrm{m}^{-2} \mathrm{~d}^{1} \mathrm{~K}^{1}\left(4^{0} \pm 5 \mathrm{ly} \mathrm{d}^{-1} \mathrm{~K}^{-1}\right)$.

Résumé. Le calcul des coefficients de transfert de chaleur à partir des gradients du bilan énergétique sur un glacier. Le transfert turbulent de chaleur sensible dans le bilan énergétique de la surface d'un glacier est paramétré par la différence de température entre la surface du glacier et l'atmosphère à la méme altitude mais en dehors de l'influence thermique du glacier. Le facteur de proportionalité est expliqué d'abord par la vitesse du frottement, par la hauteur de rugosité et par la fonction de stabilité du profil logarithmique. (ie facteur est ensuite déduit des enregistrements climatologiques, des mesures des bilans énergétiques et de leurs gradients altitudinaux dans l'Hintereisferner. On donne des exemples des composants du bilan énergétique et de leur variation avec l'altitude pour toute la saison d'ablation comme pour des courtes périodes. Les coefficients de transfert thermique ainsi calculés ont une valeur moyenne de: $1,7: 0,2 \mathrm{MJ} \mathrm{m}^{2} \mathrm{~d} \mathrm{~d}^{\mathrm{i}} \mathrm{K}$ ! $\left(40 \pm 5 \mathrm{ly} \mathrm{d}^{-1} \mathrm{~K}^{-1}\right)$.

Zusammenfassung. Die Berechnung von Wärmeäbergangszahlen aus Gradienten der Wärmebilanz entlang einer Gletscheroberfäche. Der turbulente Fluss fühlbarer Wärme wird in der Energiebilanz eines Gletscher proportional der Temperaturdifferenz gesetzt, die zwischen Gletscheroberfläche und der vom Eis unbeeinflussten Atmosphäre im gleichen Niveau besteht. Der Proportionalitätsfaktor wird zuerst als Funktion der Schubspannung, des Rauhigkeitsparameters und der Stabilitätsfunktion des logarithmischen Wind- und Temperaturprofils erklärt. Er wird dann aus Klimadaten und Messungen der Wärmebilanz und ihrer Änderung mit der Höhe am Hintereisferner bestimmt. Beispicle für die Wärmebilanz und ihre (iradienten werden für die gesamte Ablationsperiode so wie füı kürzere /,eitabschnitte gegeben. Die daraus bestimmten Wärmeübergangszahlen haben einen Mittelwert von $1,7 \div 0,2 \mathrm{MJ} \mathrm{m}^{-2} \mathrm{~d}^{-1} \mathrm{~K}^{-1}\left(40: 5 \mathrm{ly} \mathrm{d}^{-1} \mathrm{~K}^{-1}\right)$.
\end{abstract}

\section{INTRODUCTION}

Reliable measurements of the energy balance of glacier surfaces are few in number, and generally of short duration and restricted to one spot. It is often desirable to extrapolate these data in both time and space and to relate them to large-scale atmospheric processes. For this purpose the terms of the energy balance must be expressed in a way that minimizes the number of parameters referring to the glacier surface and relies more on synoptic data.

If the energy balance of the glacier could be expressed by variables that describe the state of the free atmosphere, a first step would have been accomplished in the interrelation of general circulation and glacier mass balance. The problem then would be to find a parameter of heat transfer that is valid for synoptic as well as for micrometeorological applications, i.e. for the upper and lower limit of that shallow layer in which the glacier influences the temperature and stability of the atmosphere.

The atmospheric variables and parameters can be chosen as solar radiation, terrestrial radiation emitted from atmospheric constituents and clouds, and air temperature $T_{\text {a }}$ that prevails at the level of the glacier but outside its thermal influence. The surface parameters that need to be retained are albedo $a$ and temperature $T_{0}$. By considering only melting surfaces one can further reduce the number of variables. While $a$ and $T_{0}$ link the glacier to the atmospheric radiation field in a physically obvious manner, the heat transfer from atmosphere to surface is parameterized less clearly. The heat transfer coefficient applied to the value of $T_{\mathrm{a}}-T_{\mathrm{o}}$ implies several variables determining the turbulent energy exchange in the boundary layer. 
This paper attempts to establish a value of the heat transfer coefficient $\alpha$ that fulfills the needs mentioned above. While $\alpha$ should be applicable to daily means of $T_{\mathrm{a}}$ and $T_{0}$ without further restriction, its derivation is easier when the surface is at the melting point and the latent heat flux is small compared to the sensible one. Given the uncertainty of daily values of energy fluxes and ablation measurements, the significance of $\alpha$ is even less certain and should be tested by longer records of the heat balance at one particular altitude as well as its vertical derivative.

\section{THE ENERGY BALANCE}

The balance of energy fluxes passing through any surface is zero. Fluxes directed towards the surface have a positive sign and those leaving the surface are negative. In particular, for a melting surface,

$$
Q_{\mathrm{R}}+Q_{\mathrm{S}}+Q_{\mathrm{L}}+Q_{\mathrm{M}}=\mathrm{o},
$$

where the subscripts $\mathrm{R}, \mathrm{s}, \mathrm{L}, \mathrm{M}$ respectively refer to radiation balance, sensible heat flux, and latent heat fluxes of evaporation and melting.

There are many ways of describing these fluxes in a manageable form. For the present purpose we shall choose

$$
Q_{\mathrm{R}}=(\mathbf{1}-a) G+A-E,
$$

where $G$ is the global radiation, and $A$ the downward and $E$ the upward terrestrial radiation, all in units of $\mathrm{W} \mathrm{m}^{-2}$.

$$
E=\epsilon_{0} \sigma T_{0}^{4},
$$

with $\epsilon_{0} \approx 0.98, \sigma=5.67 \times \mathrm{ro}^{-8} \mathrm{~W} \mathrm{~m}^{-2} \mathrm{~K}^{-4}$.

Values of the terrestrial downward radiation are difficult to synthesize, and therefore actual measurements of $A$ are particularly desirable over glaciers, where the vertical distribution of humidity and temperature deviates from standard values. However, for extrapolation over the glacier area, it is desirable to evaluate from the measurements an effective emissivity $\epsilon^{\star}$ defined so that

$$
A=\epsilon^{\star} \sigma T_{\mathrm{a}}^{4} \text {. }
$$

Previous investigations have shown that over alpine glaciers $Q_{\mathrm{L}}<Q_{\mathrm{S}}$ by an order of magnitude (LaChapelle, I959; Ambach and Hoinkes, 1963; Lebedeva as quoted in Hoinkes, [' $\left.{ }^{1} 964\right]$ ), whereas they are of comparable magnitude over sub-polar glaciers (Streten and Wendler, I968; Smith, i960). The flux of latent heat of evaporation will, therefore, be omitted from the present considerations.

The heat flux available for melting is

$$
Q_{\mathbf{M}}=L \cdot \hat{\partial} \cdot \hat{\imath} t=L \dot{M}
$$

where $L=335 \mathrm{~J} \mathrm{~g}^{-1}\left(80 \mathrm{cal} \mathrm{g}^{-1}\right), \hat{\imath} . M / \hat{\imath} t$ or $\dot{M}$ is the rate of melt expressed as mass per unit area and time.

The sensible heat flux can be expressed alternatively in several ways, among which are: a flux-gradient relation

and a bulk transfer

$$
Q_{\mathrm{s}}=\rho c_{p} K_{\mathrm{H}}\left(\partial T / \hat{c} z+g / c_{p}\right)
$$

$$
Q_{\mathrm{s}}=\alpha\left(T_{\mathrm{a}}-T_{\mathrm{o}}\right),
$$

where $\rho$ is air density, $c_{p}$ specific heat of air at constant pressure, $g$ acceleration of gravity, $-g / c_{p}$ the adiabatic temperature gradient, and $K_{\mathrm{H}}$ is the height-dependent eddy diffusion coefficient for heat. Attempts to express $K_{\mathrm{H}}(z)$ analytically generally rest on very restrictive assumptions, they have been summarized by Brown (1974). 
The Physical NATURE OF THE TRANSFER COEFFicient

Equation (7) implies a linear relation between $Q_{\mathrm{s}}$ and $\left(T_{\mathrm{a}}-T_{0}\right)$ despite the inherently turbulent character of the surface layer. By necessity $\alpha$ has to absorb all the effects of stability and turbulence and so will exhibit diurnal changes as well as depending on daily means of the synoptic conditions. The use of a constant bulk-transfer coefficient is therefore justified only if it is applied to periods long compared with those of the characteristic variations of the boundary-layer transfer parameters. In this paper two records, of $\mathrm{I} 4 \mathrm{~d}$ and $\mathrm{I}$ oo $\mathrm{d}$, from Hintereisferner can be interpreted as showing that over these periods the boundary layer behaved thermodynamically in a similar way.

Nonetheless it is of interest to investigate which parameters determine $\alpha$ and what are their magnitudes and ranges as found in previous investigations. In order to do this we shall integrate the flux-gradient relation over a height where the vertical divergence of coefficients of momentum and heat fluxes are negligible, e.g. o-I m (Munro and Davies, 1977; Kuhn, 1978). In such a layer, logarithmic profiles can be expected with the form

$$
\partial u / \partial z=\frac{u_{\sharp}}{\kappa z} \phi_{\mathrm{M}}(z),
$$

where $\phi_{\mathbf{M}}(z)$ is a function of stability equal to unity in neutral stratification (Businger and others, $197 \mathrm{I}$; Kraus, [1975]). The friction velocity $u_{*}$ is a measure of turbulent fluctuations of momentum, von Kármán's constant $\kappa$ is approximately 0.4. If Equation (8) is integrated for neutral conditions $\left(\phi_{M}=\mathbf{I}\right)$ and for constant stress $\left(\hat{\partial} u_{*} / \partial z=0\right)$ from the roughness height $z_{0}$ (where the mean momentum vanishes) to height $z$, three simple relations appear

$$
\begin{gathered}
u(z)=\frac{u_{*}}{\kappa} \ln \left[\frac{z}{z_{0}}\right], \\
u_{*}=u(z) \kappa / \ln \left(z / z_{0}\right), \\
z_{0}=z \exp \left(-\kappa u(z) / u_{*}\right) .
\end{gathered}
$$

For the general case, a diffusion coefficient for heat can be derived

$$
\kappa_{\mathrm{H}}(z)=\frac{u_{*} \kappa\left(z+z_{0}\right)}{\phi_{\mathrm{H}}(z)}
$$

where $\phi_{\mathrm{H}}(z)$ is defined in a similar way to $\phi_{\mathbf{M}}(z)$ and has values $\phi_{\mathrm{H}}(z)=(0.74+4.7 z / L)$ in stable stratification, $L$ being a measure of stability in units of length indirectly proportional to sensible heat flux $Q_{\mathrm{S}}$ (see, e.g. Businger and others, I97I).

For comparison with the bulk transfer (Equation (7)) the flux-gradient relation (Equation (6)) has to be integrated to that height $Z$ where $T(z)=T_{\mathrm{a}}$. Since, however, at $Z$ flux divergence of the katabatic wind regime precludes the use of logarithmic computation (Kuhn, I978), a rigorous formulation of $\alpha$ would require knowledge of the actual profiles of $T$ and $K_{\mathrm{H}}$. Under these circumstances only an approximate relationship can be derived analytically and this is done conveniently by integration to a height $z \gg z_{0}$ and $z \ll L$. In this case $z$ and $T_{\mathrm{a}}$ in Equations (14) to (16) need to be replaced by $z$ and $T(z)$.

Noting that above a melting glacier very often $\lambda T / \partial z \gg g / c_{p}$, the flux-gradient relation (Equation (6)) can be simplified. $K_{\mathrm{H}}$ is incorporated according to Equation (I 2) and Equation (6) is then rearranged:

$$
Q_{\mathrm{s}} \frac{\phi_{\mathrm{H}}(z)}{z+z_{0}} \mathrm{~d} z=\rho c_{p} u_{*} \kappa \mathrm{d} T .
$$

An upper limit of integration $z=Z$ is defined by the condition that $T(Z)=T_{\mathrm{a}}$, whereas at the lower limit $T\left(z_{0}\right)=T_{0}$. In order to avoid unnecessary complications in trying to show the relation between $\alpha$ and the surface-layer profile characteristics, $\phi_{\mathrm{H}}(z)$ may be treated as a 
constant $\bar{\phi}_{\mathrm{H}}$ and $z+z_{0} \approx z$ without loss of information. Equation (1 3 ) is then integrated to give

or

$$
\left.\begin{array}{c}
Q_{\mathrm{S}} \bar{\phi}_{\mathrm{H}} \int_{z_{\mathrm{o}}}^{z} \frac{\mathrm{d} z}{z}=\rho c_{p} u_{*} \kappa \int_{T_{\mathrm{n}}}^{T_{\mathrm{a}}} \mathrm{d} T \\
\bar{\phi}_{\mathrm{H}} \ln \left(Z / z_{\mathrm{o}}\right)=\rho c_{p} u_{*} \kappa\left(T_{\mathrm{a}}-T_{\mathrm{o}}\right),
\end{array}\right\}
$$

and

$$
Q_{\mathrm{S}}=\frac{\rho c_{p} u_{*} \kappa}{\bar{\phi}_{\mathrm{H}} \ln \left(Z / z_{0}\right)}\left(T_{\mathrm{a}}-T_{\mathrm{o}}\right) .
$$

Comparison of the right-hand sides of Equations (15) and (7) yields

$$
\alpha=\frac{\rho c_{p} u_{*} \kappa}{\bar{\phi}_{\mathrm{H}} \ln \left(Z / z_{0}\right)},
$$

which expresses the significance of the surface-layer parameters $u_{*}$ and $z_{0}$ in the bulk transfer coefficient.

Consider first the effect of surface roughness $z_{0}$. If all other quantitics in Equation (16) are kept constant the value of $\alpha$ should vary proportionally to $\mathrm{I} / \ln \left(Z / z_{0}\right)$. Table $\mathrm{I}_{\mathrm{A}}$ lists values of the transfer coefficient valid for wind speeds at $2 \mathrm{~m}$ of $5 \mathrm{~m} \mathrm{~s}^{-1}$ for various surfaces whose roughness characteristics have not been described in any greater detail by the respective authors. The relative magnitude of the $z_{0}$ in these three examples can be determined for $Z=200 \mathrm{~cm}$ from Table Iв.

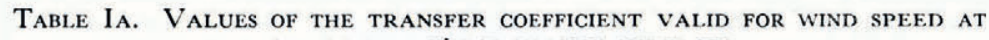
$2 \mathrm{~m}$ OF $5 \mathrm{~m} \mathrm{~s}^{-1}$ FOR VARIOUS SURFACES

$$
\begin{aligned}
& \text { "Smooth surface" } \\
& \text { (Hofmann, 1963) }
\end{aligned}
$$

Snow

$$
\text { (de Quervain, 1951) }
$$

Grass

(Frankenberger, 1955)

$\begin{array}{ccc}\mathrm{mly} \mathrm{min}^{-1} \mathrm{~K}^{-1} & \mathrm{ly} \mathrm{d}^{-1} \mathrm{~K}^{-1} & \mathrm{MJ} \mathrm{m}^{-2} \mathrm{~d}^{-1} \mathrm{~K}^{-1} \\ 10 & 14 & 0.6 \\ 19 & 27 & 1.1 \\ 22 & 32 & 1.3\end{array}$

TABLE IB. VAlues OF THE TERM $1 / \ln \left(Z / z_{0}\right)$ FOR $Z=200 \mathrm{~cm}$

$\begin{array}{cllllllll}z_{0} \mathrm{~cm} & 0.01 & 0.02 & 0.05 & 0.1 & 0.2 & 0.5 & 1.0 & 2.0 \\ 1 / \ln \left(200 \mathrm{~cm} / z_{0}\right) & 0.101 & 0.109 & 0.121 & 0.13^{2} & 0.145 & 0.167 & 0.189 & 0.217\end{array}$

The small difference of the transfer coefficient for Frankenberger's grass and de Quervain's snow implies respective values of $z_{0}$ that differ only by a factor of two. For comparison, a summary of $z_{0}$ by Deacon (1969) shows that rough snow and mown grass do indeed have similar roughness parameters. The unspecified "smooth surface" of Hofmann would correspond to sand or extremely smooth snow. Thus while an increase of $z_{0}$ by two orders of magnitude only doubles $\alpha$, Equations (10) and (16) show that $\alpha$ varies linearly with wind speed at a specified level in a logarithmic profile. Examples of profile parameters as measured over melting glaciers by various authors are presented in Table II. In most cases in this table, $u_{*}$ and $z_{0}$ were evaluated according to Equations (Io) and (I I) after logarithmic regression of $u(z)$ at three heights. Additional information on the variation of $u_{*}$ with wind speed can be found in Poggi ([1978]). 
TABLI II. EXIMPI.ES OF $u_{*}$ AND $\Sigma_{0}$ OVFR MFITING; GI.ACILRS

\begin{tabular}{|c|c|c|c|c|}
\hline Gilacier & $\begin{array}{l}u(2 \mathrm{~m}) \\
\mathrm{m}: \mathrm{i}\end{array}$ & $\mathrm{cm}_{*}$, & $\begin{array}{c}z_{0} \\
\mathrm{~cm}\end{array}$ & Source \\
\hline Saint Sorlin & $\begin{array}{l}6.6 \\
5.0 \\
4.2\end{array}$ & $\begin{array}{l}4^{6} \\
37 \\
31\end{array}$ & $\begin{array}{l}0.55 \\
0.69 \\
0.67\end{array}$ & Martin (1975, table I) \\
\hline Hornkecs & 4 & 25 & 0.17 & Hoinkes 1953 ' \\
\hline Vernagt & 3 & 17 & 0.15 & Hoinke and Lintersteiner (1952) \\
\hline Camp IV E.Ci.l.C. & 2.8 & 16 & 0.18 & 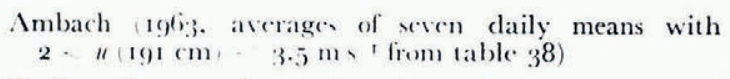 \\
\hline Zentralnyy Tuyuksu & 2 & 12 & 0.11 & Skcib $\left(1962, \|_{*}\right.$ and in evaluated frem $u$ at $\left.25,50,100 \mathrm{~cm}\right)$ \\
\hline Chogo Lungma & 1.3 & 9 & 0.20 & $\begin{array}{l}\text { Lintersteiner }\left(1958, \|_{*} \text { and } x^{\prime \prime} \text { craluated from } u \text { at } 1 \text { and }\right. \\
3 \mathrm{~m} \text { ) }\end{array}$ \\
\hline
\end{tabular}

Thus from a comparison of gradient and bulk transfer it appears that for a melting glacier surface (characterized by zo), the use of one typical value of $x$ for arbitrary periods of melting is meaningful as long as the wind speed at a specified level is comparable from one period to another.

A QuantTative Example

Using Equations (1), (2), (5), and (7) gives

$$
(1-a)\left(;+(.1-E) ; L \Delta . M / \Delta t=-\alpha\left(T_{\mathrm{a}}-T_{01}\right) .\right.
$$

where the first two terms are the short- and long-wave radiation balance, respectively, of which $a, G$, and $A$ need to be measured, while $E$ can be computed for a melting surface. The third and fourth terms involve the rate of melting and sensible heat transfer, respectively. $\dot{M}$ is determined by standard methods, $T_{\text {a }}$ requires extrapolation from nearlyy stations, and $\alpha$ is the quantity to be determined from Equation (17). Practical limitations in the measurement of melting rate and the diurnal change of stability in the boundary layer preclude the application of Equation (17) to periods other than integral numbers of days.

An example for the absolute values of the terms in Equation (1 7 ) will show that absorption of solar radiation accounts for most of the melting on the tongue of Hintereisferner. The data are taken from Wagner (unpublished), the value of $(.1-E)$ was adjusted to the lower altitude according to Equation (20).

Tongue of Hintereisferner, $2500 \mathrm{~m}$ a.s.l.

Data of 18 August 197 I

$$
\begin{aligned}
& \mathbf{1}-a=0.65 \\
& M=63 \mathrm{~kg} \mathrm{~m}^{-2}(7 \mathrm{~cm} \text { of ice }) \\
& T_{\mathrm{a}}-T_{\mathrm{o}}=5 \mathrm{~K} \\
& (\mathrm{I}-a) G=\quad \mathrm{I} 9 . \mathrm{I} \mathrm{MJ} \mathrm{m} \mathrm{J}^{-2} \mathrm{~d}^{-1}=455 \mathrm{ly} \mathrm{d}^{-1} \\
& A-E=-5.9 \mathrm{MJ} \mathrm{m}^{-2} \mathrm{~d}^{-1} \quad=-\mathrm{I}_{40 \mathrm{y} \mathrm{d}^{-1}} \\
& L i . M / \hat{\mathrm{c} t}=-2 \mathrm{I} . \mathrm{I} \mathrm{MJ} \mathrm{m} \mathrm{m}^{-2} \mathrm{~d}^{-1} \quad=-505 \mathrm{ly} \mathrm{d}^{-1} \\
& \alpha\left(T_{\mathrm{a}}-T_{\mathrm{o}}\right)=7.9 \mathrm{MJ} \mathrm{m}^{-2} \mathrm{~d}^{-1}=190 \mathrm{ly} \mathrm{d}^{-1} \\
& \alpha=\quad 1.5^{8} \mathrm{MJ} \mathrm{m}^{-2} \mathrm{~d}^{-1} \mathrm{~K}^{-1}=3^{8 \mathrm{ly} \mathrm{d}^{-1} \mathrm{~K}^{-1}}
\end{aligned}
$$

Since the convective term is the small difference between two large quantities that may be affected by several per cent error, the determination of $\alpha$ from Equation ( 17 ) suffers from a large uncertainty. However, when vertical derivatives of Equation (17) are considered, the relative magnitude of the individual terms is changed. 
Vertical gradients of the balance

When changing the altitude $h$ without changing the distance $z$ from the surface, the derivatives with respect to the vertical coordinate become

$$
\begin{aligned}
(\mathrm{I}-\tilde{a}) \hat{\imath} G / \hat{\imath} h-\tilde{G} \hat{c} a / \hat{\imath} h+\hat{\partial} A / \hat{\imath} h-\hat{\imath} E / \hat{c} h+L \hat{\imath M} / \hat{\imath} h \\
=-\tilde{\alpha}\left(\partial T_{\mathrm{a}} / \hat{c} h-\partial T_{\mathrm{o}} / \hat{c} h\right)-\left(\tilde{T}_{\mathrm{a}}-\tilde{T}_{\mathrm{o}}\right) \hat{\partial} \alpha / \hat{c} h,
\end{aligned}
$$

where the tilde denotes an average over the altitude interval which should be weighted according to the vertical derivatives of the products $a G$ and $\alpha T$ and, if these are unknown, can be approximated by linear averages. For a melting glacier surface $\partial T_{\mathrm{o}} / \partial h=0$, and from Equation (3) $\partial E / c h=0$ also. The value of $\partial \alpha / \partial h$, or the change of the transfer coefficient along the glacier surface, has not been measured to date. From the outline in the previous section, however there is little reason to expect a large, systematic variation of $u_{*}$ and $z_{0}$ with altitude over a regularly-shaped glacier tongue. Until better information is available any possible $\partial \alpha / \partial h$ must be neglected.

Typical values of the derivatives will be presented for alpine conditions. From comparison of global radiation simultaneously measured on 7 July $197 \mathrm{I}$ at Hintereisferner and in

\begin{tabular}{|c|c|c|c|c|}
\hline $\begin{array}{l}\text { Hintereisferner } \\
\text { Innsbruck }\end{array}$ & $\begin{array}{r}3000 \mathrm{~m} \\
600 \mathrm{~m}\end{array}$ & $\begin{aligned} G & =33.4 \\
& =27.2\end{aligned}$ & $\begin{array}{l}M J m^{-2} d^{-1} \\
M J m^{-2} d^{-1}\end{array}$ & $\begin{array}{l}=797 \mathrm{ly} \mathrm{d}^{-1} \\
=649 \mathrm{ly} \mathrm{d}^{-1}\end{array}$ \\
\hline Difference & $\begin{array}{c}2400 \mathrm{~m} \\
\Delta G / \Delta h\end{array}$ & $\begin{array}{l}6.2 \\
0.26\end{array}$ & $\begin{array}{l}\mathrm{MJ} \mathrm{m}^{-2} \mathrm{~d}^{-1} \\
\mathrm{MJ} \mathrm{m}^{-2} \mathrm{~d}^{-1} / \mathrm{I} 00 \mathrm{~m}\end{array}$ & $\begin{array}{l}=148 \mathrm{ly} \mathrm{d}^{-1} \\
=6 \mathrm{ly} \mathrm{d}^{-1} / 100 \mathrm{~m}\end{array}$ \\
\hline
\end{tabular}
Innsbruck $\hat{c} G / \hat{c} h$ is as follows:

The change of albedo is not linear with height. Typically there is a rapid transition from firn to ice albedo at the firn edge followed by a gradually decreasing albedo along the tongue that depends on the amount of debris covering the ice. A typical example of a transition zone on Hintereisferner is seen in Hoinkes and Rudolph (1962, fig. 6, p. 273). Glaciers that extend far below the equilibrium line may exhibit a transition zone of several hundred metres elevation separating two zones of uniform albedo on the tongue and in the névé.

Values of albedo are therefore problematic to average. A linear average was taken for the ablation period $(\tau \approx \mathrm{r}$ oo d) of Hintereisferner.

$$
\begin{aligned}
\Delta \bar{a} \mid \Delta h=0.5[a(t=\mathrm{od}, h=2900 \mathrm{~m})+a(100 \mathrm{~d}, 2900 \mathrm{~m})- \\
-a(0 \mathrm{~d}, 2500 \mathrm{~m})-a(\text { I } 20 \mathrm{~d}, 2500 \mathrm{~m})] / 400 \mathrm{~m} .
\end{aligned}
$$

Actual values supplied by Wagner's measurements (unpublished) with $0.75,0.50,0.30$, and 0.20 in the order of appearance in Equation (19) yield an albedo gradient of o. I per I $100 \mathrm{~m}$. Intuitively one expects lower values of the albedo gradient outside the transition zones, during short periods, and over smaller areas. There are, however, few data available to substantiate this impression. For the $14 \mathrm{~d}$ period discussed at the end of this paper, a value of $0.05 \pm 0.02$ per $100 \mathrm{~m}$ was adopted from measurements by Dirmhirn and Trojer (1955, p. $4^{1} 3$, fig. 5 e) and unpublished records of W. Nairz of 30 July $197 \mathrm{I}$.

The altitudinal gradient of terrestrial downward radiation $A$ was determined by two independent methods. First, the effective emissivity in Equation (4) was evaluated from measurements at Hintereisferner on 18 August 197 I (Wagner, unpublished)

$$
\begin{aligned}
A & =20.5 \mathrm{MJ} \mathrm{m}^{-2} \mathrm{~d}^{-1}\left(489 \mathrm{ly} \mathrm{d}^{-1}\right), \\
\bar{T}_{\mathrm{a}} & =275 \mathrm{~K}, \\
\epsilon^{\star} & =0.73 .
\end{aligned}
$$

Next, Equation (4) is differentiated with respect to $h$ and expanded in terms of $T$

$$
\partial A / \partial h=\epsilon^{\star} 4 \sigma \mathcal{T}_{\mathrm{a}}{ }^{3} \partial T_{\mathrm{a}} / \partial h .
$$


The free-air gradient $\partial T_{\mathrm{a}} / \partial h$ ranges between -0.5 and $-1.0 \mathrm{~K} / \mathrm{I} 00 \mathrm{~m}$, the most frequent value being $-0.6 \mathrm{~K} / 100 \mathrm{~m}$. Higher values are associated with atmospheric subsidence in fair-weather periods.

The radiative transfer coefficient defined from Equation (20)

$$
\alpha_{\mathrm{s}}=4 \sigma T_{\mathrm{a}^{3}} \text {, }
$$

has an approximate value of $5 \mathrm{~W} \mathrm{~m}^{-2} \mathrm{~K}^{-1}$ at $T=273 \mathrm{~K}\left(0.42 \mathrm{MJ} \mathrm{d}^{-1} \mathrm{~m}^{-2} \mathrm{~K}^{-1}\right.$ or io ly $\left.\mathrm{d}^{-1} \mathrm{~K}^{-1}\right)$. A value of $-0.18 \mathrm{MJ} \mathrm{d}^{-1} \mathrm{~m}^{-2} / 100 \mathrm{~m}$ or $-4 \mathrm{ly} \mathrm{d}^{-1} / 100 \mathrm{~m}$ is used for $\partial A / \hat{c} h$ in this paper, corresponding to a temperature gradient of $-0.6 \mathrm{~K} / \mathrm{r} 00 \mathrm{~m}$ and an effective emissivity of 0.7 .

An independent check of this value can be made using the data of Staudinger (1978) who measured the radiation balance at Hohe Mut $(2600 \mathrm{~m})$ and Wiese $(2000 \mathrm{~m})$ in the neighbouring valley of Obergurgl (Table III).

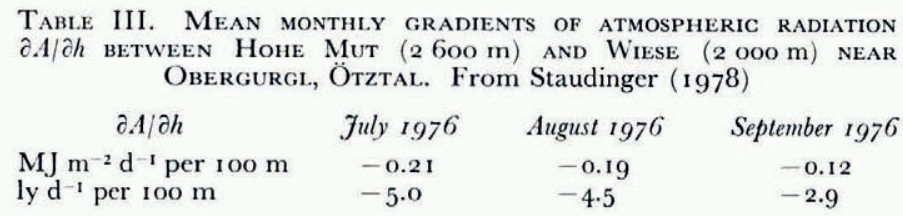

For the ablation gradient a value of $-\mathrm{I} \mathrm{m}$ water equivalent/100 $\mathrm{m}$ can be regarded as typical for the zone below the equilibrium line of Alpine glaciers (Haefeli, 1962; Schytt, 1967; Dugdale, 1972). Assuming an ablation period of roo d,

$$
\begin{aligned}
\hat{\imath} Q_{\mathrm{M}} / \hat{c} h=L \partial \dot{M} / \hat{c} h & =\left(335 \mathrm{~J} \mathrm{~g}^{-1} \mathrm{IO}^{6} \mathrm{~g} \mathrm{~m}^{-2}\right) /(\text { I oo d } 1 \text { oo m }) \\
& =3.35 \mathrm{MJ} \mathrm{d}^{-1} \mathrm{~m}^{-2} / 100 \mathrm{~m} \text { or } 80 \mathrm{ly} \mathrm{d}^{-1} / \mathrm{I} 00 \mathrm{~m}
\end{aligned}
$$

When integrating Equation (2 I) over longer time intervals, the change of the length of the ablation period with altitude may have to be taken into account. Note that in contrast to $Q_{\mathrm{M}}<\mathrm{o}$ one finds $\hat{\imath} Q_{\mathrm{M}} / \hat{c} h>\mathrm{o}$ for melting conditions.

The value of $\alpha$ can now be determined from Equation (18). Introducing the operator $\Delta \equiv \partial / \hat{c} h$ expressed per 1 oo $\mathrm{m}$, and setting $\Delta E=0$ and $\Delta T_{0}=0$ as explained before, we can rewrite Equation (18)

$$
(\mathrm{I}-\tilde{a}) \Delta G-\tilde{G} \Delta a+\Delta A+L \Delta \dot{M}=-\Delta Q_{\mathrm{s}}=-\tilde{\alpha} \Delta T_{\mathrm{a}} .
$$

The relative importance of the individual terms of Equation (22) is demonstrated in Table IV on examples of the entire ablation period and a $14 \mathrm{~d}$ sunny period in August $197 \mathrm{I}$, on Hintereisferner.

The mean of the two transfer coefficients given in Table IV (I.7 $\mathrm{MJ} \mathrm{m}^{-2} \mathrm{~d}^{-1} \mathrm{~K}^{-1}$ ) agrees well with the value of 1.6 derived from the energy balance of 18 August. The difference of the two values derived from altitudinal balance gradients, $25 \%$ of their mean, is a fair representation of the uncertainties in the input to Equation (22). Rather than attempting to give an overall error estimate, one should individually value the contributions of the errors in each term. A realistic error of $10 \%$ in the albedo gradient causes a $20 \%$ error in the transfer coefficient. On the other hand, the example of a gradient of $\alpha$ of $20 \%$ over the glacier tongue ( 2 500-2 $900 \mathrm{~m}$ ) is little more than guesswork, but it has such a large effect that a final test should be performed at the lowermost part of the tongue $(2400 \mathrm{~m})$.

Consider the maximum ablation values encountered at Hintereisferner, $7 \times 10^{6} \mathrm{~g} \mathrm{~m}^{-2}$ in Ioo d, associated with albedo minima of o. I5. Values of global radiation for the months of July to September, supplemented by an estimated $200 \mathrm{MJ} \mathrm{m}^{-2}$ for the last eight days of June, yield a short-wave radiation balance of $\mathrm{r} .75 \mathrm{GJ} \mathrm{m}^{-2}$ for the roo d ablation period. During 
TAble IV. Altitudinal gradients of the energy balance at HiNTEREISFERNER, FOR THE ENTIRE ABLATION PERIOD AND FOR 14 CLEAR DAYS IN AUgust 197 I

\begin{tabular}{|c|c|c|c|}
\hline & Ablation season & August 1971 & \\
\hline$\tilde{a}(2700 \mathrm{~m})$ & 0.45 & 0.5 & \\
\hline$\tilde{G}(2700 \mathrm{~m})$ & $\left\{\begin{array}{l}21 \cdot 4 \\
510\end{array}\right.$ & $\begin{array}{r}30 \\
700\end{array}$ & $\underset{l y d^{-1}}{M J m^{-2} d^{-1}}$ \\
\hline$\Delta a$ & o. I & 0.05 & per $100 \mathrm{~m}$ \\
\hline$\Delta G$ & $\left\{\begin{array}{l}0.26 \\
6\end{array}\right.$ & $\begin{array}{l}0.26 \\
6\end{array}$ & $\begin{array}{l}\mathrm{MJ} \mathrm{m}^{-2} \mathrm{~d}^{-1} \text { per } 100 \mathrm{~m} \\
\text { ly d }^{-1} \text { per } 100 \mathrm{~m}\end{array}$ \\
\hline$\Delta A$ & $\left\{\begin{array}{l}0.18 \\
4\end{array}\right.$ & $\begin{array}{l}0.18 \\
4\end{array}$ & $\begin{array}{l}\text { MJ m }{ }^{-2} d^{-1} \text { per } 100 \mathrm{~m} \\
\text { ly } \mathrm{d}^{-1} \text { per } 100 \mathrm{~m}\end{array}$ \\
\hline$\tau$ & 100 & 14 & days \\
\hline$\Delta M$ & $10^{6}$ & $10^{5}$ & $\mathrm{~g} \mathrm{~m}^{-2}$ per $100 \mathrm{~m}$ \\
\hline$\Delta T_{\mathrm{a}}$ & -0.6 & -0.6 & $\mathrm{~K}$ per $100 \mathrm{~m}$ \\
\hline$T_{\mathrm{a}}(2700 \mathrm{~m})$ & $\begin{array}{c}3.8 \\
\text { (July-September) }\end{array}$ & 8.2 & ${ }^{\circ} \mathrm{C}$ \\
\hline
\end{tabular}

Terms of Equation (2 $\mathrm{I}$ ) in $\mathrm{MJ} \mathrm{m}^{-2} \mathrm{~d}^{-1}$ per $\mathrm{r}$ oo $\mathrm{m}$ (values in brackets ly $\mathrm{d}^{-\mathrm{I}}$ per $\left.\mathrm{r} 00 \mathrm{~m}\right)$.

\begin{tabular}{|c|c|c|c|}
\hline$(\mathrm{I}-\tilde{a}) \Delta G$ & $+0.17 \quad(+3)$ & $+0.13 \quad(+3)$ & \\
\hline$\tilde{G} \Delta a$ & $-2.14(-50)$ & $-1.47(-35)$ & \\
\hline$\Delta A$ & $-0.18 \quad(-4)$ & $-0.18 \quad(-4)$ & \\
\hline$L \Delta \dot{M}$ & $+3.35(+80)$ & $+2.39(+57)$ & \\
\hline Residual $\Delta Q_{\mathrm{s}}$ & $-1.20(-31)$ & $-0.87(-2 \mathrm{r})$ & \\
\hline$\tilde{\alpha}$ for $\Delta \alpha=0$ & 2.00 & $\mathrm{I} .45$ & $\mathrm{MJ} \mathrm{m} \mathrm{m}^{-2} \mathrm{~d}^{-1} \mathrm{~K}^{-1}$ \\
\hline & $4^{8}$ & 35 & ly $d^{-1} K^{-1}$ \\
\hline
\end{tabular}

that time the ice emits $2.72 \mathrm{GJ} \mathrm{m}^{-2}$ and receives $2.30 \mathrm{GJ} \mathrm{m}^{-2}$ of terrestrial radiation, as extrapolated from Wagner's (unpublished) $85 \mathrm{~d}$ of measurements at $2900 \mathrm{~m}$. In order to melt $7 \times 10^{6} \mathrm{~g} \mathrm{~m}^{-2}$ an amount of $2.35 \mathrm{GJ} \mathrm{m}^{-2}$ is required and energy fluxes are balanced by a residual $Q_{\mathrm{S}}$ of ${ }_{1}$.or $\mathrm{GJ} \mathrm{m}^{-2}$. From long-term averages (1936-65) of the weather station at Vent (I $900 \mathrm{~m}$, Lauffler, unpublished) a mean temperature for July to September of $6.0^{\circ} \mathrm{C}$ is extrapolated for $T_{\mathrm{a}}(2400 \mathrm{~m})$. These values result in a transfer coefficient of 1.68 $\mathrm{MJ} \mathrm{m}$ m $^{-2} \mathrm{~d}^{-1} \mathrm{~K}^{-1}\left(40 \mathrm{ly} \mathrm{d}^{-1} \mathrm{~K}^{-1}\right)$ which is again close to the mean of the previous three examples:

\begin{tabular}{lll} 
From heat balance, I8 August I97I & I.58 & $3^{8}$ \\
terminus, entire season & 1.68 & 40 \\
From vertical gradients, August I97 I & 1.45 & 35 \\
entire season & 2.00 & $4^{8}$ \\
\cline { 2 - 3 } Mean value of the transfer coefficient & I.68 & 40
\end{tabular}

\section{Conclusions}

The value of the bulk heat transfer coefficient for sensible heat has been determined from the residual of the heat balance (Equation (1 7)) and of its vertical gradient (Equation (22)), for the entire ablation season as well as for short terms. The four coefficients thus computed yield an average of $1.68 \mathrm{MJ} \mathrm{m}^{-2} \mathrm{~d}^{-1} \mathrm{~K}^{-1}\left(40 \mathrm{ly} \mathrm{d}^{-1} \mathrm{~K}^{-1}\right) \pm 14 \%$. The good agreement of the four examples justifies the simplifications involved in the two basic equations. 
A comparison of the bulk-transfer concept and the flux-gradient relation in the surface layer reveals the dominant effect of friction velocity and a minor effect of the surface roughness on the magnitude of the transfer coefficient. Since previous investigations have shown that $u_{*}$ increases with the surface-layer wind speed, a similar variation of $\alpha$ must be expected. However, when using different lengths of records ( $1 \mathrm{~d}, \mathrm{i} 4 \mathrm{~d}$, and $\mathrm{roo} \mathrm{d}$ ) one finds that thermodynamic and dynamic conditions in the surface layer over Hintereisferner attain similar mean values and that the transfer coefficients thus derived are applicable to the averages of $\left(T_{\mathrm{a}}-T_{0}\right)$ of integral numbers of days and multiples thereof as long as portions of the relatively flat tongue are considered. The effects of strongly convex or concave shapes need to be determined in future studies.

\section{MS. received 15 December 1977 and in revised form 5 July 1978}

\section{REFERENCES}

Ambach, W. 1963. Untersuchungen zum Energieumsatz in der Ablationszone des grönländischen Inlandeises. Meddelelser om Gronland, Bd. 174, Nr. 4.

Ambach, W., and Hoinkes, H. C. 1963 . The heat balance of an Alpine snowfield (Kesselwandferner, $3240 \mathrm{~m}$, Ötztal Alps, August i I-Sept. 8, 1958). Union Géodésique et Géophysique Internationale. Association Internationale d'Hydrologie Scientifique. Assemblée générale de Berkeley, I9-8-3I-8 1963 . Commission des Neiges et des Glaces, p. $24-36$.

Brown, R. A. 1974. Analytical methods in planetary boundary-layer modelling. London, Adam Hilger.

Businger, J. A., and others. $197 \mathrm{I}$. Flux-profile relationships in the atmospheric surface layer, [by] J. A. Businger, J. C. Wyngaard, Y. Izumi, and E. F. Bradley. Journal of the Atmospheric Sciences, Vol. 28, No. 2, p. 181-89.

Deacon, E. L. 1969. Physical processes near the surface of the earth. (In Flohn, H., ed. General climatology, 2. Amsterdam, etc., Elsevier Publishing Co., p. 39-104. (World Survey of Climatology, Vol. 2.))

Dirmhirn, I., and Trojer, E. 1955. Albedountersuchungen auf dem Hintereisferner. Archiv für Meteorologie, Geophysik und Bioklimatologie, Ser. B, Bd. 6, Ht. 4, p. 400-16.

Dugdale, R. E. 1972. A statistical analysis of some measures of the state of a glacier's "health". Fournal of Glaciology, Vol. I I, No. 61, p. 73-79.

Frankenberger, E. 1955. Über Strahlung und Verdunstung. Annalen der Meteorologie, Bd. 7, Ht. I, p. 47-52.

Haefeli, R. 1962. The ablation gradient and the retreat of a glacier tongue. Union Géodésique et Géophysique Internationale. Association Internationale d'Hydrologie Scientifique. Commission des Neiges et des Glaces. Colloque d'Obergurgl, $10-9-18-9$ 1962, p. 49-59. (Publication No. $5^{8}$ de l'Association Internationale d'Hydrologie Scientifique.)

Hofmann, G. 1963. Zum Abbau der Schneedecke. Archiv für Meteorologie, Geophysik und Bioklimatologie, Ser. B, Bd. I 3 , Ht. I, p. I-20.

Hoinkes, H. C. I953. Wärmeumsatz und Ablation auf Alpengletschern. II. Hornkees (Zillertaler Alpen), September 1951. Geografiska Annaler, Årg. 35, Ht. 2, p. 1 I 6-40.

Hoinkes, H. C. [ [ ${ }^{\mathrm{I}}$ 964.] Glacial meteorology. (In Odishaw, H., ed. Research in geophysics. Vol. 2. Solid earth and interface phenomena. Cambridge, Mass., M.I.T. Press, p. 391-424.)

Hoinkes, H. C., and Rudolph, R. 1962. Mass balance studies on the Hintereisferner, Ötztal Alps, 1952-196r. Journal of Glaciology, Vol. 4, No. 33, p. 266-8o.

Hoinkes, H. C., and Untersteiner, N. 1952. Wärmeumsatz und Ablation auf Alpengletschern. I. Vernagtferner (Ötztaler Alpen), August 1950. Geografiska Annaler, Årg. 34, Ht. I-2, p. 99-158.

Kraus, H. [1975.] An energy balance model for ablation in mountainous areas. [Union Géodésique et Géophysique Internationale. Association Internationale des Sciences Hydrologiques. Commission des Neiges et Glaces.] Symposium. Neiges et Glaces. Actes du colloque de Moscow, août 1971, p. 74-82. (IAHS-AISH Publication No. 104.)

Kuhn, M. 1978. Die Höhe des Geschwindigkeitsmaximums im Gletscherwind als Parameter des Wärmehaushalts. Zentralanstalt für Meteorologie und Geodynamik in Wien. Publikation Nr. 228, p. 69/1-69/8.

LaChapelle, E. R. 1959. Annual mass and energy exchange on the Blue Glacier. Journal of Geophysical Research, Vol. 64 , No. 4 , p. $443-49$.

Lauffer, I. Unpublished. Das Klima von Vent. [Dr.phil. thesis, Universität Innsbruck, 1966.]

Martin, S. 1975. Wind regimes and heat exchange on Glacier de Saint-Sorlin. Fournal of Glaciology, Vol. 14, No. 70 , p. $9^{1-105}$.

Munro, D. S., and Davies, J. A. 1977. An experimental study of the glacier boundary layer over melting ice. Journal of Glaciology, Vol. 18, No. 8o, p. 425-36.

Poggi, A. [1978.] Étude comparative du bilan thermique en deux stations du Glacier Ampère (Iles Kerguelen). Zeitschrift für Gletscherkunde und Glazialgeologie, Bd. 13, Ht. 1-2, 1977, p. 87-97.

Quervain, M. R. de. 1951. Zur Verdunstung der Schneedecke. Archiv für Meteorologie, Geophysik und Bioklimatologie, Ser. B, Bd. 3 , Ht. 1, p. $47-64$.

Schytt, V. I 967 . A study of ablation gradient. Geografiska Annaler, Vol. 49A, Nos. 2-4, p. 327-32. 
Skeib, G. 1962. Zum Strahlungs- und Wärmehaushalt des Zentralen Tujuksu-Gletschers im Tienschan-Gebirge. Zeitschrift für Meteorologie, Bd. 16, Ht. 1, p. 1-9.

Smith, J. 1960. Glacier problems in South Georgia. Journal of Glaciology, Vol. 3, No. 28, p. 705-14.

Staudinger, M. 1978. Die Strahlungsbilanzen zweier hochalpiner Stationen während der Vegetationsperiode. Veröffentlichungen der Schweizerischen Meteorologischen Zentralanstalt, 4o, p. 236-39.

Streten, N. A., and Wendler, G. 1968. The midsummer heat balance of an Alaskan maritime glacier. Journal of Glaciology, Vol. 7, No. 51, p. 431-40.

Untersteiner, N. 1958. Glazial-meteorologische Untersuchungen im Karakorum. II. Wärmehaushalt. Archiv für Meteorologie, Geophysik und Bioklimatologie, Ser. B, Bd. 8, Ht. 2, p. 137-71.

Wagner, H. P. Unpublished. Strahlungshaushalt untersuchungen am Hintereisferner während der Ablationsperiode 1971. [Dr.phil. thesis, Universität Innsbruck, 1978.] 